\title{
Pneumonia Pneumosistis
}

\author{
I Wayan Gustawan, BNP Arhana, Putu Siadi Purniti, IB Subanada, K Dewi Kumara Wati \\ Bag/SMF Ilmu Kesehatan Anak FK UNUD/RS Sanglah Denpasar
}

\begin{abstract}
Pneumonia pnemosistis merupakan penyebab kesakitan yang serius dan kematian pada kasus gangguan sistem imun. Pneumonia pnemosistis merupakan infeksi oportunistik tersering pada kasus yang terinfeksi HIV, leukemia dan anak yang menerima transplantasi organ. Organisme penyebab adalah Pneumocystis carinii. Manifestasi klinis berupa gangguan pernapasan disertai penyakit dasarnya. Diagnosis pasti ditegakkan dengan ditemukannya organisme dalam pemeriksaan mikroskopis. Pengobatan secara umum terdiri dari tata laksana suportif dan spesifik. Trimetoprim-sulfametoksasol masih merupakan pilihan pertama baik untuk terapi maupun profilaksis. Angka kematian masih tinggi, terutama yang terlambat mendapat terapi.
\end{abstract} (Sari Pediatri 2008; 9(5):328-34).

Kata kunci: pneumonia, Pneumocystis carinii, HIV

$\mathrm{P}$ neumonia pnemosistis (PNP) merupakan jenis infeksi oportunistik yang disebabkan oleh Pneumocystis carinii, terjadi pada kasus yang mendapat terapi imunosupresi kronik atau yang mengalami gangguan sistem imun. Pada individu dengan status imun baik, tidak tampak gejala (asimtomatik). ${ }^{1}$ Pneumonia pnemosistis merupakan kejadian umum pada penderita AIDS di negara-negara maju. Di negara berkembang insidennya tidak diketahui dengan pasti karena data belum tersedia. Sebelum penggunaan obat-obat profilaksis, hampir 80\% kasus AIDS menderita PNP. ${ }^{2}$ Pada saat awal epidemi HIV, kejadian PNP pada anak HIV adalah

\section{Alamat korespondensi}

Dr. I. Wayan Gustawan, Bag/SMF Ilmu Kesehatan Anak FK UNUD/ RSUP Sanglah Denpasar Jln. Pulau Nias Denpasar Bali. Telepon/Fax: 0361-244038 atau 0361-257387 E-mail: yanawantara@yahoo.com
1,3 kasus per 100 anak-tahun dari bayi sampai remaja dan meningkat menjadi 9,3 kasus per 100 anak-tahun pada tahun pertama kehidupan. Namun terjadi penurunan insiden PNP dari tahun 1992-1997, khususnya setelah penggunaan terapi anti retrovirus aktif., ${ }^{3,4}$ Hallett, dkk ${ }^{5}$ melaporkan PNP dijumpai pada kasus leukemia limfoblastik akut, transplantasi ginjal, penyakit lupus, dan neuroblastoma.

\section{Etiologi}

Pneumonia pnemosistis adalah pneumonia yang disebabkan oleh jamur Pneumocystis carinii. Beberapa kepustakaan menyebutkan penyebab PNP adalah Pneumocystis jiroveci. ${ }^{6-8}$ Pneumocystis jiroveci merupakan varian dari Pneumocystis carinii yang ditemukan pada manusia. ${ }^{2,8}$ Analisis terhadap ribosom RNA pada tahun 1988 dilaporkan dari pneumocystis menunjukkan 
adanya phylogenetic-linkage terhadap kelompok fungi dan berdasarkan informasi genomik organisme ini dikelompokan dalam famili jamur ascomycetous. ${ }^{8-11}$

Organisme pneumosistis telah teridentifikasi dari semua mamalia. $P$. carinii yang menginfeksi manusia, diberi nama $P$. jiroveci. ${ }^{2,8,11}$ Organisme $P$. carinii mempunyai sifat khas yaitu pneumosistis yang menginfeksi hewan tidak dapat menginfeksi manusia, namun jika ditularkan pada hewan yang sejenis akan meningkatkan virulensi. ${ }^{8}$ Secara morfologi ini terdiri dari dua bentuk yaitu tropozoit dengan dinding tipis dan bentuk kista yang mempunyai dinding tebal. Bentuk tropozoit (trofik) berukuran 1-4 $\mu \mathrm{m}$, sedangkan bentuk kista mempunyai dinding tebal dengan ukuran 5-8 $\mu \mathrm{m}$, mengandung 4-8 inti. ${ }^{11,12}$ Siklus hidup $P$. carinii terdiri dari 2 siklus yaitu siklus aseksual dan seksual. Siklus aseksual melibatkan bentuk trofik (tropozoit) dan siklus seksual melibatkan bentuk kista, akhir dari siklus adalah terbentuknya kista-kista yang baru. ${ }^{11}$ Gambar 1 memperlihatkan siklus hidup dari P. carinii. ${ }^{13}$

\section{Patogenesis}

Jamur $P$. carinii merupakan organisme yang jarang menyebabkan penyakit pada individu yang mempunyai limfosit $T$ normal, infeksi terjadi pada individu yang mengalami defek pada sistem imun. ${ }^{12,14}$ Portentree P. carinii masuk secara inhalasi, menetap di alveoli, kemudian hidup di lapisan surfaktan di permukaan epitel alveoli tipe I, sehingga dikatakan sebagai patogen

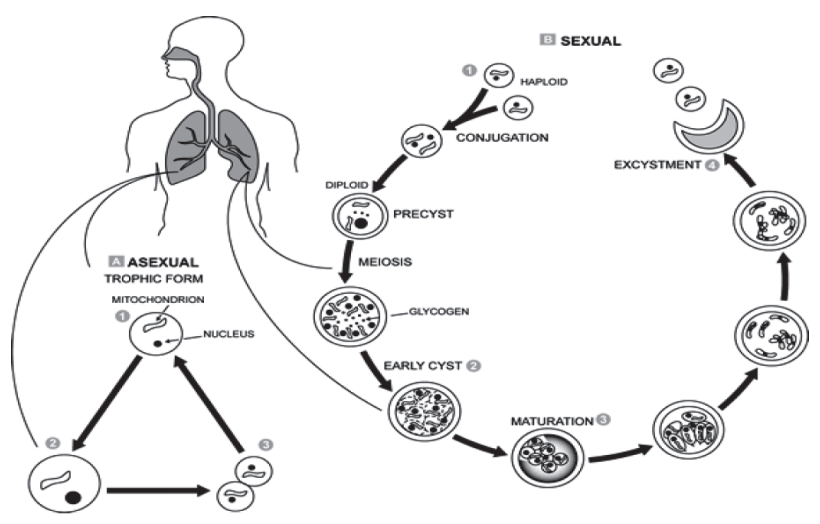

Gambar 1. Siklus hidup Pneumocystis carinii Dikutip dari Collier L, $1998 .{ }^{13}$ ekstraselular. ${ }^{11}$ Pada keadaan tertentu organisme ini menetap di lapisan tersebut dan mengalami reaktivasi saat terjadi gangguan sistem imun. Pada keadaan ini P. carinii bertambah jumlahnya dan mengisi alveoli. Dengan mekanisme yang belum diketahui secara jelas, terjadi peningkatan permeabilitas kapiler alveoli dan kerusakan sel alveoli tipe I. ${ }^{12}$ Gambaran histologi yang dijumpai adalah alveoli terisi oleh sel-sel epitel alveoli yang mengalami deskuamasi, monosit, organisme dan cairan, menimbulkan gambaran berbusa, tampak seperti gambaran sarang tawon. ${ }^{14,15}$

\section{Patofisiologi}

Untuk mengontrol PNP terjadi respon inflamasi yang efektif pada pejamu. Namun demikian inflamasi yang berlebihan juga dapat menyebabkan jejas paru selama infeksi. Pneumonia pneumosistis yang berat ditandai dengan infiltrasi neutrofil pada paru yang menyebabkan kerusakan alveolar difus, gangguan pertukaran gas dan gagal napas. Jadi sesungguhnya, gangguan napas dan kematian lebih berkorelasi dengan beratnya inflamasi dibandingkan dengan organisme yang masuk. ${ }^{9}$

Respon imun melawan $P$. carinii melibatkan interaksi kompleks antara limfosit T CD4+, makrofag alveolar, neutrofil dan mediator terlarut yang memfasilitasi pembersihan kuman. Makrofag alveolar berperan sebagai alat pertahanan paru dengan memakan dan menghancurkan organisme yang masuk ke dalam paru. Jika tidak ada opsonin pada cairan di permukaan epitel, maka makrofag berperan memakan P. carinii ini. Setelah dimakan makrofag, organisme dimasukkan dalam fagolisosom dan akhirnya dihancurkan. ${ }^{9,12}$

Fungsi makrofag terganggu pada kasus AIDS, keganasan atau keduanya, sehingga pembersihan $P$. carinii menjadi berkurang. Pada binatang dengan penurunan makrofag, resolusi $P$. carinii menjadi terganggu. Makrofag memproduksi berbagai ragam sitokin proinflamasi, kemokin dan metabolit eicosanoid sebagai respon untuk memfagositosis $P$. carinii. Mediator proinflamasi berperan dalam eradikasi $P$. carinii, namun juga menyebabkan kerusakan jaringan paru. ${ }^{9}$

Pada infeksi $P$. carinii, peran sel T CD4+ paling penting, baik pada manusia maupun binatang. Risiko terjadinya infeksi meningkat jika jumlah sel T CD4+ di bawah $200 \mathrm{sel} / \mathrm{mm}^{3}$. Sel CD4+ berfungsi sebagai 
sel memori untuk menumbuhkan respon inflamasi pada pejamu dengan cara menarik dan mengaktivasi sel-sel imun efektor, seperti monosit dan makrofag. ${ }^{9}, 12,14$ Bagaimana mekanisme sel T CD4+ sebagai respon terhadap infeksi $P$. carinii baru dipelajari dalam beberapa tahun terakhir. Mediator proinflamasi TNF $\alpha$ dan IL-1 yang dilepaskan makrofag diduga memegang peran penting mengenali respon imun yang dimediasi oleh sel T CD4+. Sel ini berproliferasi sebagai respon terhadap antigen $P$. carinii kemudian melepaskan mediator sitokin, seperti limfotaktin dan interferon gamma (INF $\gamma$ ). Limfotaktin adalah suatu kemokin yang berfungsi sebagai penarik sel-sel limfosit pada PNP. Diikuti oleh INF $\gamma$ merangsang makrofag melepaskan TNF $\alpha$, superoksida dan spesies nitrogen reaktif yang semuanya berperan untuk menghancurkan organisme. ${ }^{9,12}$

\section{Manifestasi Klinis}

Proses transmisi PNP belum diketahui dengan jelas, demikian pula tentang peran faktor lingkungan. Teori awal yang dianut adalah terjadi reaktivasi $P$. carinii laten akibat sistem imun yang menurun. Dewasa ini terdapat bukti bahwa transmisi orang ke orang merupakan cara tersering mendapatkan infeksi baru, walaupun kemungkinan lingkungan sebagai reservoar juga bisa terjadi. Orang-orang yang tampak sehat dapat berperan sebagai karier. ${ }^{9}$

Terdapat dua gambaran klinis PNP. Pertama, tipe infantil dominan dijumpai pada bayi dengan kondisi lemah dan bayi prematur. Kejadian cenderung pada umur 3-6 bulan awitan lambat, gejala tidak spesifik seperti minum dan aktifitas menurun. Takipne merupakan gejala awal dan sering terdengar ronki. Gejala memberat dalam 1-2 minggu, ditandai dengan takipne, napas cuping hidung, retraksi sternal dan sianosis, namun demam dan batuk jarang ditemui. Jika tidak diobati 25\%-50\% pasien akan meninggal. Kedua, pada anak dengan status imunosupresi. Awitan terjadi tiba-tiba dan demam merupakan gejala khas untuk tipe ini. Gejala lain yang dijumpai takipne, batuk, sianosis, napas cuping hidung, coryza, diare. Gejala berjalan progresif dan sering berakhir fatal. ${ }^{16,17}$

Pneumonia pneumosistis merupakan salah satu tanda bahwa seorang yang terinfeksi HIV telah masuk stadium AIDS. Jumlah sel T CD4+ pada pasien ini umumnya $<200 / \mathrm{mm}^{3}$. Gejalanya sesak progresif

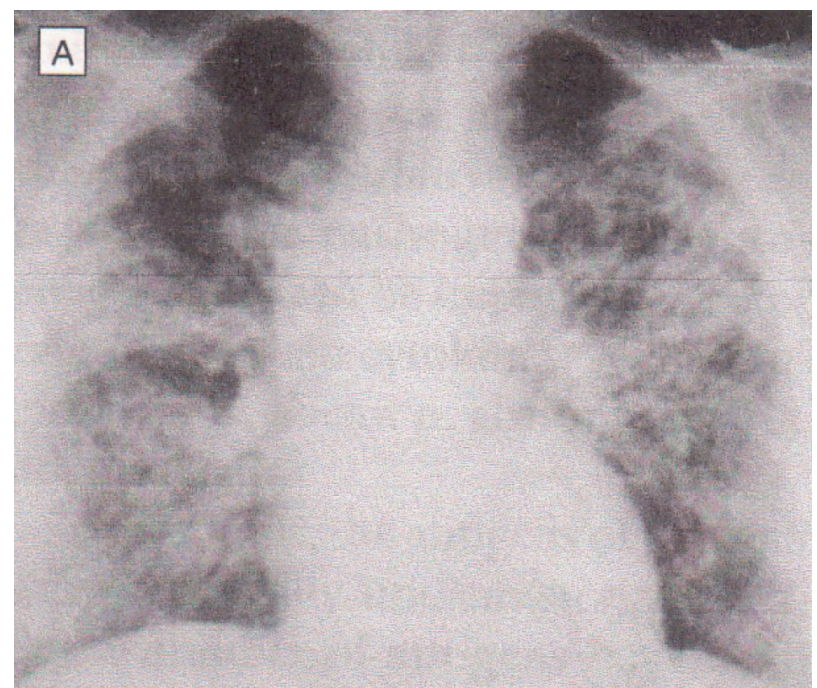

Gambar 2. Gambaran radiologi kasus Pneumonia pneumosistis Dikutip dari Kovacs JA dkk, 2001. ${ }^{10}$

dengan awitan ringan, batuk tidak produktif serta subfebril. Sesak napas akut disertai nyeri dada pleuritik mengindikasikan te rjadi pneumotoraks. Pada pemeriksaan fisik dijumpai takipne, takikardi, namun auskultasi paru sering dalam batas normal. ${ }^{6,9,16}$

Pada anak dengan AIDS, keadaan lain sering timbul mendahului timbulnya PNP. Keadaan tersebut adalah gagal tumbuh (70\%), kandidiasis mukosa mulut (67\%), kelainan neurologis (52\%), diare (7\%) dan pneumonia cytomegalovirus (4\%). ${ }^{16}$ Pasien PNP tanpa AIDS umumnya ditandai dengan insufisiensi nafas dengan awitan yang tidak jelas, yang mungkin berkorelasi dengan penurunan dan peningkatan dosis imunosupresan. Angka kematian 30\%-60\%, tergantung faktor risiko. Risiko kematian lebih tinggi pada kasus kanker dibandingkan dengan kasus yang menjalani transplantasi atau menderita penyakit kolagen. ${ }^{6,9,16}$

Gambaran radiologik yang tipikal untuk PNP yaitu infiltrat interstitial parahiler bilateral, yang menjadi lebih homogen dan difus bila penyakit bertambah progresif. Gambaran lain yang bisa terjadi yaitu nodul soliter atau multipel, infiltrat pada lobus atas, pneumatokel dan pneumotoraks. Efusi pleura dan limfadenopati toraks sangat jarang terjadi. Jika gambaran radiologik dalam batas normal, maka dengan CT-scan beresolusi tinggi dapat ditemukan bayangan ground glass (kaca susu) atau lesi kistik. ${ }^{9,18}$ 
Gambaran laboratorium tidak spesifik untuk infeksi ini dan pada umumnya menggambarkan keadaan penyakit dasar. Kadar laktat dehidrogenase (LDH) serum biasanya meningkat sebagai akibat kerusakan paru. Pada pemeriksaan analisa gas darah dijumpai $\mathrm{PaO}_{2}$ kurang dari $70 \mathrm{mmHg}$ pada kasus yang berat. ${ }^{19}$

\section{Diagnosis}

Pneumonia pnemosistis mungkin sulit didiagnosis oleh karena gejala tidak spesifik, dan disebabkan penggunaan obat profilaksis HIV atau karena infeksi simultan oleh banyak organisme pada pasien gangguan sistem imun. Diagnosis pasti ditegakkan dengan pemeriksaan mikroskopis untuk mengidentifikasi $P$. carinii pada spesimen yang relevan seperti sputum, cairan bronkoalveolar atau jaringan paru, mengingat organisme tidak dapat dibiakkan. ${ }^{16,19,20}$ Jika hasil pemeriksaan sputum negatif, sebaiknya dilanjutkan dengan pemeriksaan bronkoskopi dan bilasan bronkoalveolar. Biopsi transbronkogenik atau biopsi paru jarang dilakukan. Bentuk trofik fungi $P$. carinii dapat diidentifikasi dengan pengecatan papanicolaou yang dimodifikasi, Wright-Giemsa atau Gram-Weigert. Sementara bentuk kista dapat diwarnai dengan Gomeri methenamine silver, cresyl echt violet, toluidine blue $O$ atau colcofluor white. Pemeriksaan dengan antibodi monoklonal untuk pneumocystis pada sputum induksi memiliki sensitifitas dan spesifisitas yang lebih tinggi dibandingkan pemeriksaan dengan pengecatan konvensional. Keuntungan pemeriksaan antibodi monoklonal, mampu mendeteksi baik bentuk trofik maupun kista sekaligus, ini penting karena pada PNP lebih banyak ditemukan bentuk trofik. ${ }^{9,20,21}$ Penggunaan polymerase chain reaction (PCR) untuk diagnostik banyak diteliti saat ini. Sensitifitas dan spesifisitas pemeriksaan PCR lebih tinggi dibandingkan dengan pengecatan konvensional, baik untuk bahan sputum maupun cucian bronkoalveolar. Namun pemeriksaan PCR pada serum tampaknya belum bermanfaat untuk menegakkan diagnosis. ${ }^{7,9}$

\section{Diagnosis banding}

Gambaran klinis sering tidak spesifik sehingga menyulitkan para klinisi untuk mengetahui diagnosis spesifik. Gambaran klinis sangat bervariasi tergantung status imun pasien. ${ }^{16}$ Diagnosis banding PNP adalah influenza, infeksi virus RSV, cytomegalovirus, adenovirus, pneumonia bakteri dan jamur. ${ }^{19}$ Berbagai organisme patogen dapat menyerang paru pasien dengan gangguan status imun, seperti virus, bakteri, jamur dan protozoa. ${ }^{16}$

Untuk membedakan penyebab pneumonia selain dengan menemukan organisme penyebab, gambaran radiologi mungkin dapat membantu mengarahkan ke organisme penyebab seperti terlihat dalam Tabel 1 . Gambaran radiologi yang sering ditemukan adalah pneumonia interstisial difus atau abses alveoli, gambaran lobar atau lobular (bronkopneumonia), noduler, kavitas, dan abses paru. ${ }^{16}$

Tabel 1. Gambaran radiologi paru sesuai organisme penyebab pada pasien gangguan sistem imun ${ }^{16}$

\begin{tabular}{lll}
\hline $\begin{array}{l}\text { Pneumonia interstisial } \\
\text { difus/abses alveoli }\end{array}$ & \multicolumn{1}{c}{$\begin{array}{c}\text { Lobar atau lobular } \\
\text { (bronkhopneumonia) }\end{array}$} & \multicolumn{1}{c}{$\begin{array}{c}\text { Noduler, kavitas, } \\
\text { abses paru }\end{array}$} \\
\hline $\begin{array}{l}\text { Pneumocystis carinii } \\
\text { Bakteri (Streptococcus pneumoniae, } \\
\text { Haemophilus influenza, Staphylococcus } \\
\text { aureus, gram negatif) }\end{array}$ & $\begin{array}{l}\text { bakteri (Staphylococcus aureus, } \\
\text { gram negatif) }\end{array}$ \\
Cytomegalovirus & Nocardia & C. neoformans \\
Cryptococcus neoformans & C. neoformans & Nocardia \\
Aspergillus sp. & Aspergillus sp. & Aspergillus sp \\
Candida albicans & Mucor & Legionella pneumophilia \\
Respiratory syncytial virus & Mycobacterium tuberculosis & Pneumocystis carinii \\
Varicella-zoster virus & Legionella pneumophilia & Mycobacterium tuberculosis \\
Adenovirus & Adenovirus & \\
Histoplasma capsulatum & & \\
\hline
\end{tabular}

Dikutip dari Hughes WT. ${ }^{16}$ 


\section{Tata laksana}

Tata laksana kasus PNP sama dengan tata laksana penyakit lain, terdiri dari tata laksana umum dan spesifik. ${ }^{16,19}$ Penyakit ringan dapat menjalani rawat jalan, diberikan terapi oral dan dilakukan observasi. Pasien yang mengalami hipoksemia signifikan harus rawat inap untuk mendapat terapi intravena dan bila memburuk dengan gejala gagal napas diindikasikan untuk dirawat ruang terapi intensif.?

Tata laksana umum berupa pemberian terapi suportif seperti pemberian oksigen dan makanan. Oksigen diberikan untuk menjaga tekanan oksigen arteri $\left(\mathrm{PaO}_{2}\right)$ di atas $70 \mathrm{mmHg}$. Ventilator diperlukan bila $\mathrm{PaO}_{2}$ kurang dari $60 \mathrm{mmHg}$. Pemberian bronkodilator dapat dicoba walaupun tidak banyak membantu. Pasien harus dirawat dalam kamar terisolasi. ${ }^{16,19}$

Penanganan spesifik adalah pemberian obat-obatan seperti tampak pada Tabel 2. ${ }^{9}$ Trimetoprim-sulfametoksasol merupakan terapi yang paling efektif untuk PNP. Cara kerja trimetoprim belum diketahui secara pasti, sedangkan sulfametoksasol dapat menghambat sintesis folat pada pembentukan enzim dihydropteroate synthase (DHPS).$^{10}$ Dosis pemberian $15-20 \mathrm{mg} / \mathrm{kg} / \mathrm{hari}$ untuk trimetoprim dan $75-100 \mathrm{mg} / \mathrm{kg} / \mathrm{hari}$ untuk sulfametoksasol, terbagi dalam 4 dosis, secara oral. Lama pengobatan 3 minggu untuk kasus AIDS dan 2 minggu untuk kasus bukan AIDS.,19

Pemberian kortikosteroid sebagai tambahan terapi dipercaya dapat meningkatkan harapan hidup pada pasien dengan PNP derajat sedang dan berat. Kortikosteroid bermanfaat untuk pasien PNP dengan $\mathrm{HIV}$ yang mengalami hipoksemia $(\mathrm{PaO} 2$ arteri $<70$ $\mathrm{mmHg}$ atau gradien alveolar-arteri $>35$ ). Pada keadaan ini, pasien harus diberikan prednison $60 \mathrm{mg} /$ hari 2 kali sehari selama 5 hari, selanjutnya $40 \mathrm{mg}$ /hari pada hari ke-6 sampai hari ke-11, lalu $20 \mathrm{mg} /$ hari pada hari ke-13 sampai hari ke-21. Pada pasien tanpa AIDS, namun dengan PNP yang berat, pemberian prednison $60 \mathrm{mg} / \mathrm{lebih}$ per hari memberikan hasil lebih baik dibandingkan pemberian dosis rendah. ${ }^{1,9,13,22-24}$

\section{Profilaksis}

Profilaksis primer pada orang dewasa yang terinfeksi HIV, termasuk pada wanita hamil dan pasien yang mendapat terapi anti retrovirus aktif, harus dimulai jika jumlah sel T CD4+ $<200 / \mathrm{mm}^{3}$ atau jika ada riwayat kandidiasis orofaringeal. ${ }^{9}$ Anak yang dilahirkan dari ibu HIV harus diberikan profilaksis dengan trimetoprim-sulfametoksasol dimulai pada umur 4-6 minggu. Profilaksis pada anak dihentikan bila pada pemeriksaan selanjutnya tidak terbukti terinfeksi HIV. Anak yang menderita HIV dan anak dengan status infeksi belum jelas, profilaksis harus terus diberikan untuk 1 tahun pertama hidupnya. ${ }^{25,26}$ Tabel 3 memperlihatkan indikasi pemberian profilaksis pada anak.

Pasien HIV yang sebelumnya pernah menderita PNP harus mendapat profilaksis sekunder jangka panjang, kecuali telah terjadi rekonstitusi dari sistem imun sebagai hasil pemberian terapi anti retrovirus aktif, yaitu dengan jumlah sel CD4+ $>200 / \mathrm{mm}^{3}$. Profilaksis diberikan kembali jika jumlah sel CD4+ kembali menurun di bawah $200 / \mathrm{mm}^{3}$. 9,25,27

Profilaksis juga diberikan pada kasus sindrom defisiensi imun berat, mendapat transplantasi organ, atau mendapat terapi imunosupresif untuk penyakit kanker. Dalam suatu studi retrospektif, pemberian kortikosteroid yang setara dengan $16 \mathrm{mg}$ prednison atau lebih selama periode 8 bulan pada kasus tanpa AIDS memiliki risiko signifikan mendapat PNP.

Tabel 2. Daftar dan dosis obat untuk Pneumonia pneumosistis ${ }^{9}$

\begin{tabular}{lllc}
\hline Nama obat & \multicolumn{1}{c}{ Dosis } & Cara Pemberian & Komentar \\
\hline Trimetoprim- Sulfametoksasol & $15-20 \mathrm{mg} / \mathrm{kg}$ & Oral atau & Pilihan \\
& $75-100 \mathrm{mg} / \mathrm{kg}$ & intravena & pertama \\
& Sehari dibagi dalam 4 dosis & & \\
Pentamidin & $4 \mathrm{mg} / \mathrm{kg}$ perhari/ & intravena/ & Pilihan \\
& $600 \mathrm{mg}$ per hari & aerosol & alternatif \\
\hline
\end{tabular}

Dikutip dari Thomas CF dkk, 2004. ${ }^{9}$ 
I Wayan Gustawan dkk: Pneumonia Pneumosistis

Tabel 3. Rekomendasi profilaksis PNP dan CD4+ monitoring untuk bayi yang terpapar HIV dan anak yang terinfeksi HIV, berdasarkan umur dan status infeksi ${ }^{26}$

\begin{tabular}{lll}
\hline Umur/status infeksi HIV & \multicolumn{1}{c}{ Profilaksis PNP } & Monitoring CD4+ \\
\hline Lahir - 4-6 minggu, terpapar HIV & Tidak diberikan & 1 bulan \\
4-6 minggu sampai 4 bulan, terpapar HIV & Diberikan & 3 bulan \\
4-12 bulan & Diberikan & 6,9, dan 12 bulan \\
Infeksi HIV atau indeterminate & Tidak diberikan & Tidak perlu \\
Infeksi HIV dapat disingkirkan & Diberikan bila : & Setiap 3-4 bulan \\
1-5 tahun, terinfeksi HIV & Jumlah CD4+<500 sel/ul & \\
& CD4+ persentase $<15 \%$ & \\
6-12 tahun, terinfeksi HIV & Diberikan bila: & \\
& Jumlah CD4+ $<200 \mathrm{sel} / \mathrm{ul}$ & \\
& CD4+ persentase $<15 \%$ & \\
\hline
\end{tabular}

Dikutip dari Centers for disease control and prevention. ${ }^{26}$

Pengamatan yang sama dijumpai pada pasien kanker atau pasien penyakit kolagen yang mendapat terapi kortikosteroid. . $22,23,25,27^{2}$

Obat yang dianjurkan untuk profilaksis PNP adalah trimetoprim-sulfametoksasol dengan dosis 5 $\mathrm{mg} / \mathrm{kgBB} /$ hari untuk trimetoprim dan $25 \mathrm{mg} / \mathrm{kgBB} /$ hari untuk sulfametoksasol, satu kali sehari, diberikan 3 kali dalam seminggu atau boleh setiap hari. Alternatif lain untuk profilaksis adalah dapson $(2 \mathrm{mg} /$ $\mathrm{kgBB} /$ hari; maksimal $100 \mathrm{mg} /$ dosis) setiap hari per oral atau $4 \mathrm{mg} / \mathrm{kgBB} /$ hari setiap minggu; maksimum $200 \mathrm{mg}$, atovaquone $(30 \mathrm{mg} / \mathrm{kgBB} / \mathrm{hari})$, setiap hari selama 1-3 bulan dan anak yang berumur lebih dari 24 bulan ( $45 \mathrm{mg} / \mathrm{kgBB} / \mathrm{hari}$ ) selama $4-23$ bulan. Profilaksis diberikan selama status imun belum membaik. ${ }^{1}$

\section{Prognosis}

Angka kematian masih tinggi pada kasus gangguan sistem imun yang terlambat mendapat terapi, ${ }^{19}$ kematian terjadi dalam 3-4 minggu setelah awitan penyakit. ${ }^{1}$ Dengan perbaikan manajemen penanganan, terjadi penurunan angka kematian sampai $15 \%$ pada kasus terinfeksi HIV, namun masih tetap tinggi (40\%) pada kasus bukan HIV. Faktor-faktor yang mungkin berpengaruh adalah jumlah neutrofil dan kadar IL-8 pada cairan bronkoalveolar, abnormalitas foto toraks, kadar LDH dan albumin serum dan pengalaman rumah sakit dalam merawat kasus HIV. ${ }^{12}$

\section{Kesimpulan}

Pneumonia pnemosistis merupakan jenis infeksi oportunistik yang disebabkan oleh Pneumocystis carinii, terjadi pada kasus dengan terapi imunosupresi kronik atau gangguan sistem imun. Infeksi yang berat ditandai dengan infiltrasi neutrofil pada paru yang menyebabkan kerusakan alveolar difus, gangguan pertukaran gas dan gagal napas. Manifestasi klinis berupa gangguan pernapasan disertai penyakit dasar. Gangguan napas dan kematian disebabkan karena beratnya inflamasi. Diagnosis pasti ditegakkan dengan ditemukannya organisme dalam pemeriksaan mikroskopis. Tata laksana terdiri dari tata laksana secara suportif dan spesifik. Trimetoprim-sulfametoksasol masih merupakan pilihan pertama baik untuk terapi maupun profilaksis. Angka kematian masih tinggi, terutama yang terlambat mendapat terapi.

\section{Daftar Pustaka}

1. Hughes WT. Pneumocystis carinii. Dalam: Behrman RE, Kliegman RM, Jenson HB, penyunting. Nelson textbook of pediatrics. Edisi ke-17. Philadelphia: Saunders; 2004. h. 1154-5.

2. Bellamy R. Pneumocystis pneumonia in people with HIV. Clin Evid 2005; 13:1-16.

3. Morris A, Lundgren JD, Masur H, Walzer PD, Hanson DL, Frederick T, dkk. Current epidemiology of pneumocystis pneumonia. Emerg Infect Dis 2004; 10:1713-20. 
4. Kaplan JE, Hanson D, Dworkin MS, Frederick T, Bertolli J, Lindegren ML, dkk. Epidemiology of human immunodeficiency virus-associated opportunistic epidemiology of human immunodeficiency virus-associated opportunistic therapy. Clinical Infectious Diseases 2000; 30:S5-14.

5. Hallett JJ, Fickenscher LG, Ablin AR. Pneumocystis carinii pneumonia in children. Western J Med 1977; 126:441-4.

6. Schreibman TS. Pneumocystis carinii pneumonia. Emedicine. 2004 (diakses tanggal 5 Januari 2006). Diproleh dari: URL:http://www.emedicine.com.

7. Miller RF, Wakefield AE. Pneumocystis carinii genotypes and severity of pneumonia. Lancet 1999; 353:2039-40.

8. Stringer JR, Beard CB, Miller RF, Wakefield AE. A new name (Pneumocystis jiroveci) for pneumocystis from humans. Emerg Infect Dis 2002; 8:891-6.

9. Thomas CF, Limper AH. Pneumocystis pneumonia. New Engl J Med 2004; 350:2487-98.

10. Kovacs JA, Gill VJ, Meshnick S, Masur H. New insight into transmission, diagnosis, and drug treatment of pneumocystis carinii pneumonia. JAMA 2001; 286:245060.

11. Brooks GF, Butel JS, Morse, SA. Medical microbiology. Edisi ke-23. Boston: McGraw Hill; 2004. h. 6501.

12. Walzer PD. Pneumocystis carinii infection. Dalam: Braunwald E, Hauser SL, Fauci AS, Longo DL, Kasper DL, Jameson JL, penyunting. Principles of internal medicine. Edisi ke-16. Boston: McGraw Hill; 2001. h. 1182-5.

13. Collier L, Balows A, Sussman M. Topley and Wilson's microbiology and microbial Infections. Edisi ke-9. New York: Arnold Publishing; 1998. h. 674

14. Ryan KJ. Pneumocystis carinii. Dalam: Ryan KJ, Ray CG, penyunting. Medical microbiology. Edisi ke-4. New York: McGraw Hill; 2004. h. 685-9.

15. Rubin E. Essential pathology. Edisi ke-3. Philadelphia: Lippincott Williams \& Wilkins; 2001. h. 318.

16. Hughes WT. Pneumocystis carinii pneumonitis. Dalam: Chernick V, Boat TF, Kendig EL, penyunting. Kendig's disorders ot the respiratory tract in children. Edisi ke 6 . Philadelphia: Saunders; 1998. h. 503-11.
17. Sattler F, Nichols L, Hirano L, Hiti A, Hofman F, Hughlett C, dkk. Nonspecific interstitiel pneumonitis mimicking Pneumocystis carinii pneumonia. Am J Respir Crit Care Med 1997; 156:912-7.

18. Chow C, Templeton PA, White CS. Lung cysts associated with Pneumocystis carinii pneumonia: radiographic characteristics, natural history, and complications. AJR 1993; 161:527-31.

19. Hay WW, Levin MJ, Hayward AR, Sondheimer JM. Current pediatric diagnosis \& treatment. Edisi ke-16. Boston: McGraw Hill; 2003. h. 1249-51.

20. Cruciani M, Marcati P, Malena M, Bosco O, Serpelloni G, Mengoli C. Meta-analysis of diagnostic procedures for Pneumocystis carinii pneumonia in HIV-1-infected patients. Eur Respir J 2002; 20:982-9.

21. Teisa A, Tabaczka P. The use of polarization microscopy in the diagnosis of pneumocystis pneumonia. Arch Pathol Lab Med 2004; 128:363-4.

22. Ioannidis J, Wilkinson D. HIV: prevention of opportunistic infections. Clin Evid 2005; 13:832-51.

23. Ledergerber B, Mocroft A, Reiss P, Furrer H, Kirk O, Bickel $\mathrm{M}, d k k$. Discontinuation of secondary prophylaxis against Pneumocystis carinii pneumonia in patients with HIV infection who have a response to antiretroviral therapy. New Engl J Med 2001; 344:168-74.

24. Hocker B, Wendt C, Nahimana A, Tonshoff B, Hauser PM. Molecular evidence of Pneumocystis transmission in pediatric transplant unit. Emerg Infect Dis 2005; 11:330-2.

25. Masur H, Kaplan JE, Holmes KK. Guidelines for preventing opportunistic infections among HIV-infected persons-2002 Recommendations of the U.S. Public Health Service and the Infectious Diseases Society of America. Ann Intern Med. 2002; 137:435-77.

26. Centers for Disease Control and Prevention: 1995 Revised guidelines for prophylaxis againts Pneumocystis carinii pneumonia for children infected with or perinatally exposed to human immunodeficiency virus. MMWR 1995; 44(RR-4):1-18.

27. Furrer H, Egger M, Opravil M, Bernasconi E, Hirschel $\mathrm{B}$, Battegay M, dkk. Discontinuation of primary prophylaxis against pneumocystis carinii pneumonia in HIV1 -infected adults treated with combination antiretroviral therapy. N Engl J Med 1999; 240:1301-6. 